\title{
Growth and volumetric production of eucalyptus clones in different planting spaces
}

\author{
Wesley Gomes Silva ${ }^{1}$, Darcy Maria da Conceição Laura dos Santos ${ }^{1}$, Ana Paula Leite Lima ${ }^{1}$, \\ Filipi Duran Mattos ${ }^{1}$, Sebastião Ferreira Lima ${ }^{1}$, Rita de Cássia Mariano de Paula ${ }^{1}$ \\ ${ }^{1}$ Universidade Federal de Mato Grosso do Sul, Campus de Chapadão do Sul, Chapadão do Sul, Mato Grosso do Sul, Brasil. E-mail: \\ wesley_gomes00@hotmail.com, darcy_mclaurasantos@hotmail.com, paula.leite@ufms.br, filipi_vb@hotmail.com, \\ sebastiao.lima@ufms.br, rcmp92@hotmail.com
}

Received: 14/03/2019; Accepted: 21/05/2019.

\begin{abstract}
In forest stands, the ideal planting spacing can provide each tree with enough space for its establishment, aiming at greater growth and wood quality, according to the objective of planting. The objective of this study was to evaluate the growth in height, diameter, and volumetric production of three eucalyptus clones planted in different spacings. The experiment was carried out in an area belonging to Campo Bom Farm, in Chapadão do Sul, MS. A randomized block design was used in a factorial scheme, combining six spacings $(2.5 \times 0.5 \mathrm{~m} ; 2.5 \times 1.0 \mathrm{~m} ; 2.5 \times 2.0 \mathrm{~m} ; 3.0 \times$ $0.5 \mathrm{~m} ; 3.0 \times 1.0 \mathrm{~m}$ and $3.0 \times 2.0 \mathrm{~m}$ ) and three clone of Eucalyptus grandis $\times$ Eucalyptus urophylla (GG 680, GG 157 and GG 100) with three replications. The diameter at breast height (DBH) and height of all plants were evaluated at 12,18, 24, and 32 months after planting. At 32 months, the cubage of a tree per plot was performed to obtain the volume of wood per tree and hectare. In the largest spacings, the highest average plant heights were observed. The growth of plant height was reduced from 24 months of age, except for the GG 680 clone, at $2.5 \times 2.0$ $\mathrm{m}$ and $2.5 \times 1.0 \mathrm{~m}$ spacings, and in GG 100 clone, at $2.5 \times 1.0 \mathrm{~m}$ spacing. The average diameter and volume per tree increased with the spacing for the three clones, while the volume per area was higher in the denser spacing. Wood volume production per area was dependent on the spacing used for the three clones.
\end{abstract}

Keywords: Energy Forests, Wood Yield, Planting Density.

\section{Crescimento e produção volumétrica de clones de eucalipto em diferentes espaçamentos de plantio}

\section{RESUMO}

Em povoamentos florestais, o espaçamento de plantio ideal é aquele capaz de proporcionar a cada árvore o espaço suficiente para seu estabelecimento, visando maior crescimento e qualidade da madeira, conforme o objetivo do plantio. Assim, o objetivo deste estudo foi avaliar o crescimento em altura, diâmetro e a produção volumétrica de três clones de eucalipto plantados em diferentes espaçamentos. $\mathrm{O}$ experimento foi desenvolvido em área pertencente à Fazenda Campo Bom, em Chapadão do Sul, MS. O delineamento utilizado foi blocos casualizados em esquema fatorial, combinando seis espaçamentos (2,5 x 0,5 m; $2,5 \times 1,0 \mathrm{~m} ; 2,5 \times 2,0 \mathrm{~m} ; 3,0 \times 0,5 \mathrm{~m} ; 3,0 \times 1,0$ $\mathrm{m}$ e $3,0 \times 2,0 \mathrm{~m}$ ) e três clones de Eucalyptus grandis x E. urophylla (GG 680, GG 157 e GG 100) com três repetições. Avaliou-se o diâmetro, a altura do peito (DAP) e a altura de todas as plantas das parcelas, aos 12, 18, 24 e 32 meses após plantio. Aos 32 meses, fez-se a cubagem de uma árvore média por parcela para a obtenção do volume de madeira por árvore e por hectare. Nos maiores espaçamentos, observaram-se as maiores alturas médias. Houve redução do crescimento em altura a partir dos 24 meses de idade, exceto para o clone GG680 no espaçamento 2,5 x 2,0 m e 2,5 x 1,0 m, e no GG100 no espaçamento 2,5 x 1,0 m. O diâmetro médio e o volume por árvore aumentaram com o espaçamento para os três clones, enquanto o volume por área foi maior nos espaçamentos mais adensados. A produção de volume de madeira por área foi dependente do espaçamento utilizado para os três clones.

Palavras-chave: Florestas energéticas, Produtividade de madeira, Densidade de plantio. 


\section{Introduction}

The world's energy matrix is based on the use of fossil fuels, being expensive, insecure, and harmful to the environment. Thus, many countries look for other sources of energy, such as biomass (Brito, 2007). According to Protásio et al. (2014), the use of biomass for energy generation has the advantage of being renewable, less polluting and reducing the emission of carbon dioxide into the atmosphere when compared to fossil fuels.

Considering the use of forest biomass for energy purposes, the genus Eucalyptus has been the most used for its production, due to its good adaptation to soil and climate variations in Brazil (Moulin et al., 2015), presenting rapid growth, high productivity and, due to their ability to provide quality products in shorter time intervals than other forest species (Souza et al., 2009; Lopes et al., 2017).

With the demand for forest biomass for energy generation, the concept of energy forests emerges which, from the sharp reduction in plant spacing, aims to produce more biomass per unit area, using shorter rotations (Harrington et al., 2009) than those adopted in conventional forest plantations.

Planting spacing interferes with the production of a forest stand, both qualitatively and quantitatively (Stape et al., 2010; Ferreira et al., 2014; Moulin et al., 2015). In denser spacing, there is a higher number of plants per hectare, although the trees have lower diameter development and wood volume per plant (Oliveira Neto et al., 2010). However, the volume and biomass production per unit area is expected to be higher due to the greater use of growth resources, but along the crop rotation it is expected that this effect will be minimized (Leite et al., 1997).

In the larger spacings, there are fewer trees per unit of area. However, they tend to be larger, which consequently provides a greater volume of wood per plant (Oliveira Neto et al., 2010; Inoue et al., 2011; Lima and Garcia, 2011). However, considering a shorter rotation than those conventionally used, lower wood volume per hectare is expected when compared to stands with higher population density.

The main purpose of the forest plantation with high density is to produce, in short rotation, a larger amount of forest biomass per unit of area. However, each eucalyptus species or clone may behave differently using the same planting spacing. Thus, it is essential to know the behavior of different genotypes of the genus Eucalyptus conducted in dense systems.

The objective of this study was to evaluate the growth and volumetric production of three Eucalyptus grandis $\mathrm{x}$ E. urophylla clones planted in different spacings.

\section{Material and Methods}

This study was carried out in an area of Campo Bom Farm, in Chapadão do Sul, MS. The soil of the region is classified as Latossolo Vermelho distrófico, with clayey texture (Embrapa, 2013) and the climate is tropical humid (Aw) with the rainy season in summer and dry in winter, and an annual average rainfall of 1,850 $\mathrm{mm}$ (Cunha et al., 2013).

The experimental design used for the variables, total height $(\mathrm{TH})$ and diameter at breast height $(\mathrm{DBH})$ was randomized blocks in a factorial scheme with the splitplot in time, with a combination of three eucalyptus clones, six spacings and four evaluation times, with three repetitions. The clones used were from Eucalyptus grandis x E. urophylla hybrids (GG 680, GG 157, and GG 100). The spacings tested were: $2.5 \mathrm{~m} \times 0.5 \mathrm{~m} ; 2.5$ $\mathrm{m} \times 1.0 \mathrm{~m} ; 2.5 \mathrm{~m}$ x $2.0 \mathrm{~m} ; 3.0 \mathrm{~m}$ x $0.5 \mathrm{~m} ; 3.0 \mathrm{~m}$ x $1.0 \mathrm{~m}$ and $3.0 \mathrm{~m} \mathrm{x} 2.0 \mathrm{~m}$ and the evaluation times were at 12 , 18, 24 and 32 months after planting. Each experimental plot consisted of four rows with 12 plants each. The useful area of each plot consisted of the two central rows with ten plants each. The diameter, taken at $1.30 \mathrm{~m}$ from the ground $(\mathrm{DBH})$ and the $\mathrm{TH}$ were obtained from the 20 trees that constituted the useful plot area.

The experimental design used for the volumetric production variable was in randomized blocks in a $3 \times 6$ factorial scheme, with three replications. The treatments were formed by the combination of the same clones and spacings used for the TH and DBH variables. To estimate the volumetric production, the $\mathrm{TH}$ at 32 months was determined, measuring 10 trees in each plot and, to estimate the height of the other trees in these plots, the Trorey linear model was adjusted, with $\mathrm{R}^{2}=0$, 7401 and $\mathrm{Syx} \%=12.36 \%$, and all coefficients were significant at $5 \%$ probability.

$T H=3.464613+1.476709 \times D B H-0.045822 \times D B H^{2}+e$

At 32 months, to determine the solid wood volume, the mean square diameter per plot was determined, and then a tree of average diameter per plot was selected and felled, totaling 54 felled trees. Then, rigorous cubage of the trees was performed using the Smalian method, with sections every $2.0 \mathrm{~m}$ from the DBH (Soares et al., 2007). The estimated volume of the trees measured in the plots was performed using the Spurr linear model, with $\mathrm{R}^{2}=0.9582$ and $\mathrm{Syx} \%=7.64 \%$, whose coefficients were significant at $5 \%$ probability.

$\mathrm{Vol}=0.001627+0.000038 \times D B H^{2} \times \mathrm{TH}+e$

Data were subjected to analysis of variance. For the qualitative factors (clone and spacing), the average of treatments of the variables HT, DC, and volumetric production were compared by Tukey test at 5\% probability. For the quantitative factor (time), regression models were adjusted for the variables HT and DC, at $5 \%$ probability. 


\section{Results and Discussion \\ Height growth}

The plant height of eucalyptus was significantly influenced by the interaction between the studied clone, the planting spacing, and the evaluation time. There was interaction, at $5 \%$ probability, between clone, spacing, and evaluation time (Table 1). In the interaction, only the evaluation time factor was significant at 5\% probability (Figure 1). For the evaluation time factor, regression was performed by generating the equations (Table 2) for each height growth curve in each spacing within each clone. There was no significant variation in other factors.

In general, for the three clones studied, it can be observed that the growth in height as a function of planting spacing began to show a difference by around 18 months of planting (Figure 1). Probably due to the absence of competition until this age. Besides, it can be noted that up to 24 months, there was more marked height growth, especially for clones GG 680 and GG 157 , in the wider spacings ( $3.0 \times 2.0 \mathrm{~m}$ and $2.5 \times 2.0 \mathrm{~m})$. From this age, for the three clones, a decrease in growth rate was noted in most spacings. For Oliveira Neto et al. (2010), the reduction of average plant height in smaller spacing can be attributed to the establishment of earlier competition, established between plants for environmental resources, resulting in lower uniformity between trees due to the higher number of dominated trees.

For clone GG 680, only at $2.5 \times 2.0 \mathrm{~m}$ and $3.0 \times 2.0$ $\mathrm{m}$ spacings, the plants kept the accented height growth. For plants of clone GG 157, only at 2.5 x 2.0 m spacing did this same behavior occur (Figure 1).
According to Oliveira Neto et al. (2010), growth in height has variable behavior in relation to planting spacing. Leles et al. (2001), evaluating the growth of $E$. camaldulensis and E. pellita in different spacings, observed a diversified behavior of the species in the studied spacings. E. camaldulensis had no difference in height in wider spacing. At the $3.0 \mathrm{~m} \mathrm{x} 2.0 \mathrm{~m}, 3.0 \mathrm{~m} \mathrm{x}$ $1.5 \mathrm{~m}$ and $3.0 \mathrm{~m} \times 1.0 \mathrm{~m}$ spacings, there was a decrease in height with increasing density. For E. pellita, the highest heights were observed in the smallest and largest spacings $(3.0 \mathrm{~m} \times 1.5 \mathrm{~m}, 3.0 \mathrm{~m} \times 1.0 \mathrm{~m}$ and 9.0 $\mathrm{m} \times 9.0 \mathrm{~m}$ ).

For clone GG 100, throughout the evaluated period, only at $2.5 \times 1.0 \mathrm{~m}$ spacing did the plants kept accented height growth. For this clone, it was also observed that, over time, there was a more marked differentiation in plant height according to the spacing than that observed for the other clones (Figure 1). When comparing the height reached by the trees in the $3.0 \times 0.5 \mathrm{~m}$ and $3.0 \mathrm{x}$ $2.0 \mathrm{~m}$ spacings for clone GG 100, there was an average reduction of $32 \%$ for the smallest spacing, from 18 months of age. While for clones GG 680 and GG 157, this reduction was $14 \%$ and $6 \%$, respectively.

This behavior of clone GG 100 may indicate higher sensitivity of this clone to the row spacing with higher density. However, in the $2.5 \mathrm{~m} \times 0.5 \mathrm{~m}$ spacing, with the same spacing between plants in the row, it was found that up to 24 months the plants had accented height growth, higher than the $3.0 \mathrm{~m} \times 1.0 \mathrm{~m}, 2.5 \mathrm{~m} \mathrm{x} 1.0 \mathrm{~m}$, and $2.5 \mathrm{~m} \times 2.0 \mathrm{~m}$ spacings. Some factor related to soil or its preparation, such as the occurrence of some compaction layer, may have influenced the result obtained for $3.0 \mathrm{~m}$ x $0.5 \mathrm{~m}$ spacing.

Table 1. Variance analysis of interactions between clone and spacing over time in relation to plant height values.

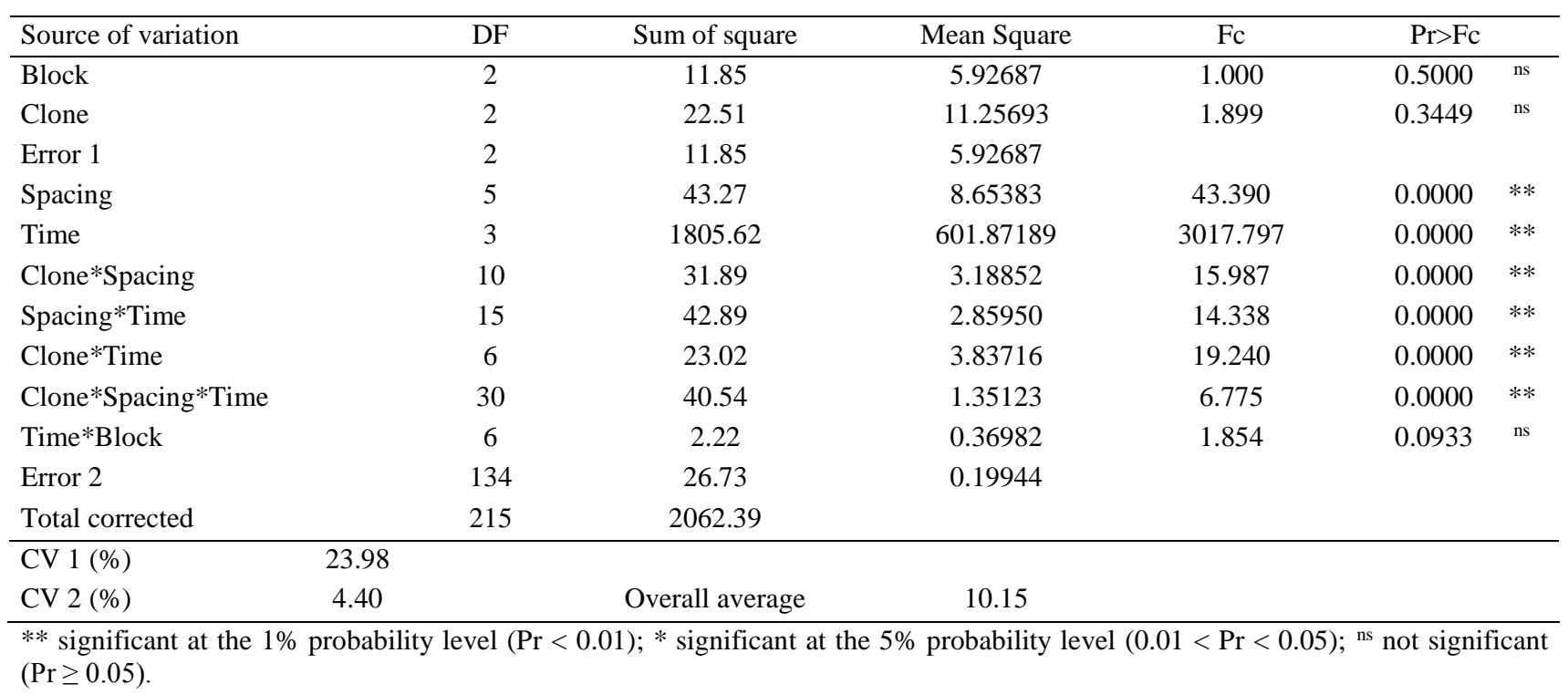


Table 2. Growth curve equations of plant height $\left(\Upsilon=\beta_{0}+\beta_{1} * \chi^{+}+\beta_{2} * \chi^{2}\right)$ obtained from regression, for time unfolding within each clone for each spacing.

\begin{tabular}{|c|c|c|c|c|c|}
\hline \multicolumn{2}{|r|}{ Treatments } & \multicolumn{3}{|c|}{ Coefficients } & \multirow{2}{*}{$\mathrm{R}^{2}(\%)$} \\
\hline Clone & Spacing & $\beta_{0}$ & $\beta_{1}$ & $\beta_{2}$ & \\
\hline \multirow{6}{*}{ GG 680} & $2.5 \mathrm{~m} \times 0.5 \mathrm{~m}$ & -4.431246 & 1.138589 & -0.019404 & 96.98 \\
\hline & $2.5 \mathrm{~m} \times 1.0 \mathrm{~m}$ & -6.912019 & 1.285285 & -0.020475 & 98.73 \\
\hline & $2.5 \mathrm{~m} \mathrm{x} 2.0 \mathrm{~m}$ & -7.993133 & 1.459515 & -0.023761 & 97.93 \\
\hline & $3.0 \mathrm{~m} \times 0.5 \mathrm{~m}$ & -7.375143 & 1.412829 & 0.024901 & 96.75 \\
\hline & $3.0 \mathrm{~m} \mathrm{x} 1.0 \mathrm{~m}$ & -8.695161 & 1.570769 & -0.027342 & 97.72 \\
\hline & $3.0 \mathrm{~m} \times 2.0 \mathrm{~m}$ & -12.528731 & 1.877503 & -0.032219 & 98.58 \\
\hline \multirow{6}{*}{ GG 157} & $2.5 \mathrm{~m} \times 0.5 \mathrm{~m}$ & -6.391493 & 1.245859 & -0.021703 & 94.81 \\
\hline & $2.5 \mathrm{~m} \times 1.0 \mathrm{~m}$ & -6.504378 & 1.303726 & -0.022693 & 96.91 \\
\hline & $2.5 \mathrm{~m} \mathrm{x} 2.0 \mathrm{~m}$ & -7.427900 & 1.391453 & -0.022363 & 89.60 \\
\hline & $3.0 \mathrm{~m} \times 0.5 \mathrm{~m}$ & -6.114750 & 1.315423 & -0.023035 & 95.22 \\
\hline & $3.0 \mathrm{~m} \times 1.0 \mathrm{~m}$ & -5.421847 & 1.179831 & -0.020089 & 84.12 \\
\hline & $3.0 \mathrm{~m} \times 2.0 \mathrm{~m}$ & -8.731455 & 1.567433 & -0.027547 & 77.12 \\
\hline \multirow{6}{*}{ GG 100} & $2.5 \mathrm{~m} \times 0.5 \mathrm{~m}$ & -12.334249 & 1.841671 & -0.033410 & 99.35 \\
\hline & $2.5 \mathrm{~m} \times 1.0 \mathrm{~m}$ & -6.100732 & 1.106548 & -0.015145 & 96.94 \\
\hline & $2.5 \mathrm{~m} \mathrm{x} 2.0 \mathrm{~m}$ & -10.754887 & 1.607240 & -0.027229 & 98.41 \\
\hline & $3.0 \mathrm{~m} \times 0.5 \mathrm{~m}$ & -4.265411 & 1.004813 & -0.016926 & 81.91 \\
\hline & $3.0 \mathrm{~m} \mathrm{x} 1.0 \mathrm{~m}$ & -9.065013 & 1.520741 & -0.026520 & 98.43 \\
\hline & $3.0 \mathrm{~m} \times 2.0 \mathrm{~m}$ & -16.153043 & 2.192883 & -0.039149 & 99.34 \\
\hline
\end{tabular}
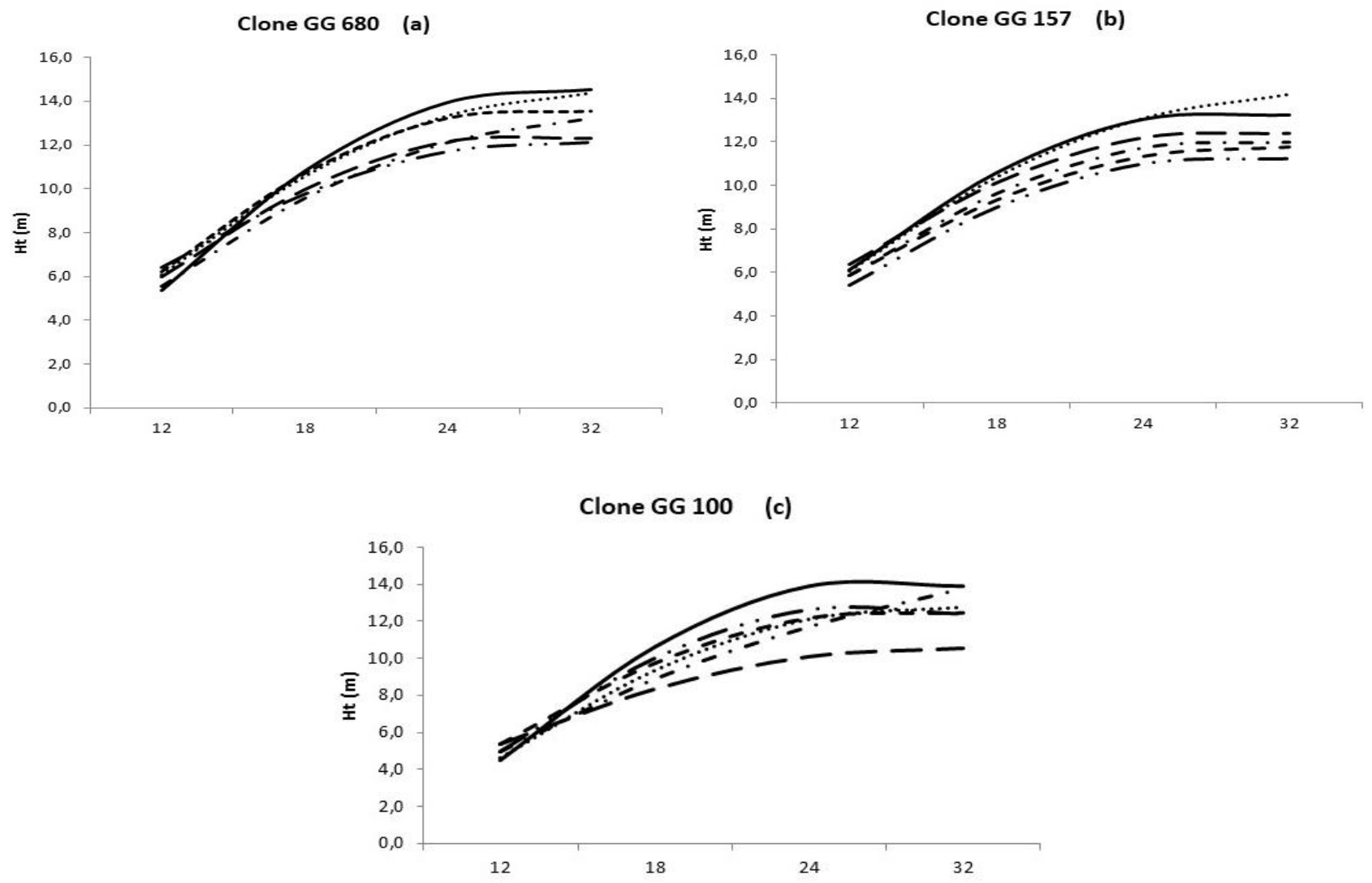

Tempo após o plantio (meses)

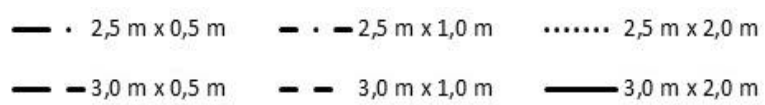

Figure 1. Plant height growth (TH) curves for clones GG 680 (a), GG 157 (b) and GG 100 (c), for the different spacings studied. 
At $2.5 \mathrm{~m} \times 1.0 \mathrm{~m}$ spacing, from 18 to 32 months of age, there was no change in the slope of the growth curve, showing that the plants are in full height growth, reaching at the 32 months to the same height of plants at $3.0 \mathrm{~m} \times 2.0 \mathrm{~m}$ spacing. However, it was observed that at $3.0 \mathrm{~m} \times 2.0 \mathrm{~m}$ spacing, from 24 to 32 months of age, there was a decrease in plant growth, so that at 32 months they had lower height than at 24 months, similar to that observed in the $2.5 \mathrm{~m} \times 0.5 \mathrm{~m}$ and $3.0 \mathrm{~m} \mathrm{x} 1.0 \mathrm{~m}$ spacings.

This was due to the break of the top of trees that were detected in the experiment around 24 months of age, occurring for all three clones, but more sharply for the clone GG 100 (Figure 1).

\section{Diameter growth}

Variance analysis for diameter growth also showed interaction for the factors, clone, spacing, and time at $5 \%$ probability (Table 3). Overall, the three clones studied showed similar behavior of diameter growth at all ages evaluated (Table 4).

Significant differences were found only at $2.5 \mathrm{~m} \mathrm{x}$ $1.0 \mathrm{~m}$ spacing at 28 months and at $2.5 \mathrm{~m} \mathrm{x} 2.0 \mathrm{~m}$ spacing at 24 and 32 months (Table 4). In the latter, for both ages, clone GG 157 presented the largest average diameters $(10.41 \mathrm{~cm}$ and $11.16 \mathrm{~cm}$, respectively), and the lowest values were observed in the clone GG 680 $(8.18 \mathrm{~cm}$ and $9.10 \mathrm{~cm}$, respectively).

There was no significant difference in diameter at 12 months for any of the clones studied (Table 5). Also, there was no significant difference for clone GG 680 at 18 months. This result can be explained by the fact that, until this age, the competition between plants did not start, making the growth uniform, regardless of the spacing used.

For clone GG 680, only at 24 and 32 months, significant differences in diameter were detected according to the planting spacing (Table 5). The highest diameter was observed for the largest spacing $(3.0 \mathrm{~m} \mathrm{x}$ $2.0 \mathrm{~m}$ ), with average values of $10.14 \mathrm{~cm}$ and $11.50 \mathrm{~cm}$ at 24 and 32 months, respectively.

The influence of spacing on diameter was observed at 18, 24, and 32 months of age in clone GG 157 (Table $5)$. For the three evaluation ages, the highest values were observed at $2.5 \mathrm{~m} \mathrm{x} 2.0 \mathrm{~m}$ spacing $(8.42 \mathrm{~cm}, 10.41$ $\mathrm{cm}$ and $11.16 \mathrm{~cm}$ at 18,24 and 32 months, respectively), and the lowest values in the smallest spacings $(2.5 \mathrm{~m} \mathrm{x}$ $0.5 \mathrm{~m}$ and $3.0 \mathrm{~m} \times 0,5 \mathrm{~m}$ ).

The observed behavior for clone GG 100 was similar to that of the other clones (Table 5). At 18, 24 and 32 months, the largest diameters were observed at $3.0 \mathrm{~m} \times 2.0 \mathrm{~m}$ spacing, with values of $7.68 \mathrm{~cm}, 10.18$ $\mathrm{cm}$, and $11.06 \mathrm{~cm}$, respectively. The lowest values were observed at $3.0 \mathrm{~m} \times 0.5 \mathrm{~m}$ spacing, with diameters of $5.10 \mathrm{~cm}, 6.25 \mathrm{~cm}$, and $7.59 \mathrm{~cm}$, respectively.

Different authors have observed the largest diameter growth caused by the increase of plant spacing for various woody species (Bernardo et al., 1998; Harrington et al., 2009; Inoue et al., 2011; Ferreira et al., 2014; Lopes et al., 2017). As the space between plants increases, there is greater light interception by their crowns, resulting in higher production of photoassimilates (Oliveira Neto et al., 2010), as well as greater availability of water and nutrients (Stape et al., 2010; Ferreira et al., 2014), since the root systems of plants present more space to develop.

Table 3. Variance analysis of interactions between clone and spacing over time in relation to the diameter at breast height (DBH) values.

\begin{tabular}{|c|c|c|c|c|c|c|c|}
\hline \multirow{2}{*}{$\begin{array}{l}\text { Source of variation } \\
\text { Block }\end{array}$} & & \multirow{2}{*}{$\begin{array}{l}\mathrm{DF} \\
2\end{array}$} & \multirow{2}{*}{$\begin{array}{c}\text { Sum of square } \\
1.83\end{array}$} & \multirow{2}{*}{$\begin{array}{c}\text { Mean square } \\
0.91415\end{array}$} & \multirow{2}{*}{$\frac{\mathrm{Fc}}{1.000}$} & \multicolumn{2}{|c|}{$\mathrm{Pr}>\mathrm{Fc}$} \\
\hline & & & & & & 0.5000 & ns \\
\hline Clone & & 2 & 8.08 & 4.04156 & 4.421 & 0.1845 & ns \\
\hline Error 1 & & 2 & 1.83 & 0.91415 & & & \\
\hline Spacing & & 5 & 166.41 & 33.28111 & 227.843 & 0.0000 & $* *$ \\
\hline Time & & 3 & 799.61 & 266.53725 & 1824.720 & 0.0000 & $* *$ \\
\hline Clone*Spacing & & 10 & 23.30 & 2.32997 & 15.951 & 0.0000 & $* *$ \\
\hline Spacing*Time & & 15 & 39.86 & 2.65758 & 18.194 & 0.0000 & $* *$ \\
\hline Clone*Time & & 6 & 3.78 & 0.63054 & 4.317 & 0.0005 & $* *$ \\
\hline Clone*Spacing*Time & & 30 & 7.27 & 0.24246 & 1.660 & 0.0274 & $* *$ \\
\hline Time*Block & & 6 & 1.64 & 0.27361 & 1.873 & 0.0899 & ns \\
\hline Error 2 & & 134 & 19.57 & 0.14607 & & & \\
\hline Total corrected & & 215 & 10.73 & & & & \\
\hline CV $1(\%)$ & 13.65 & & & & & & \\
\hline CV $2(\%)$ & 5.46 & & Overall average & 7.00 & & & \\
\hline
\end{tabular}


Table 4. Mean diameter at breast height (DBH), in centimeters, for clones GG 680, GG 157 and GG 100, within each spacing, at 12 , 18,24 and 32 months after planting.

\begin{tabular}{|c|c|c|c|c|c|c|c|c|c|}
\hline \multirow{3}{*}{$\begin{array}{c}\text { Spacing }(\mathrm{m}) \\
2.5 \times 0.5\end{array}$} & \multirow{3}{*}{$\begin{array}{l}\text { Clone } \\
\text { GG } 680\end{array}$} & \multicolumn{8}{|c|}{ Diameter at breast height $(\mathrm{DBH})(\mathrm{cm})$} \\
\hline & & \multicolumn{2}{|c|}{12 months } & \multicolumn{2}{|c|}{18 months } & \multicolumn{2}{|c|}{24 months } & \multicolumn{2}{|c|}{32 months } \\
\hline & & 4.15 & $\mathrm{a}$ & 5.89 & $\mathrm{a}$ & 6.74 & $\mathrm{a}$ & 7.65 & $\mathrm{a}$ \\
\hline \multirow{2}{*}{8000 plants ha ${ }^{-1}$} & GG 157 & 3.26 & a & 5.32 & $\mathrm{a}$ & 6.33 & a & 7.49 & $\mathrm{a}$ \\
\hline & GG 100 & 3.53 & $\mathrm{a}$ & 5.55 & $\mathrm{a}$ & 6.62 & $\mathrm{a}$ & 7.96 & $\mathrm{a}$ \\
\hline \multirow{2}{*}{$2.5 \times 1.0$} & GG 680 & 4.48 & $\mathrm{a}$ & 6.01 & $\mathrm{~b}$ & 8.08 & $\mathrm{a}$ & 8.97 & $\mathrm{a}$ \\
\hline & GG 157 & 4.08 & a & 7.75 & $\mathrm{a}$ & 8.18 & $\mathrm{~b}$ & 8.88 & $\mathrm{a}$ \\
\hline 4000 plants ha $^{-1}$ & GG 100 & 3.60 & $\mathrm{a}$ & 6.08 & $a b$ & 7.83 & $\mathrm{a}$ & 8.84 & $\mathrm{a}$ \\
\hline \multirow{2}{*}{$2.5 \times 2.0$} & GG 680 & 4.50 & $\mathrm{a}$ & 6.74 & $\mathrm{a}$ & 8.18 & $\mathrm{~b}$ & 9.10 & $\mathrm{~b}$ \\
\hline & GG 157 & 5.16 & $\mathrm{a}$ & 8.42 & $\mathrm{a}$ & 10.41 & $\mathrm{a}$ & 11.16 & $\mathrm{a}$ \\
\hline 2000 plants ha ${ }^{-1}$ & GG 100 & 3.60 & $\mathrm{a}$ & 6.87 & $\mathrm{a}$ & 9.15 & $a b$ & 10.08 & $a b$ \\
\hline \multirow{2}{*}{$3.0 \times 0.5$} & GG 680 & 4.02 & $\mathrm{a}$ & 5.88 & $\mathrm{a}$ & 6.86 & $\mathrm{a}$ & 7.69 & $\mathrm{a}$ \\
\hline & GG 157 & 4.06 & $\mathrm{a}$ & 6.08 & $\mathrm{a}$ & 7.20 & $\mathrm{a}$ & 8.28 & $\mathrm{a}$ \\
\hline 6666 plants ha' & GG 100 & 3.13 & $\mathrm{a}$ & 5.10 & $\mathrm{a}$ & 6.25 & $\mathrm{a}$ & 7.59 & $\mathrm{a}$ \\
\hline \multirow{2}{*}{$3.0 \times 1.0$} & GG 680 & 4.57 & $\mathrm{a}$ & 7.27 & $\mathrm{a}$ & 8.79 & $\mathrm{a}$ & 9.54 & $\mathrm{a}$ \\
\hline & GG 157 & 4.36 & $\mathrm{a}$ & 6.63 & $\mathrm{a}$ & 8.01 & $\mathrm{a}$ & 8.95 & $\mathrm{a}$ \\
\hline 3333 plants ha ${ }^{-1}$ & GG 100 & 4.01 & $\mathrm{a}$ & 6.42 & $\mathrm{a}$ & 8.06 & $\mathrm{a}$ & 8.92 & $\mathrm{a}$ \\
\hline \multirow{2}{*}{$3.0 \times 2.0$} & GG 680 & 4.35 & $\mathrm{a}$ & 7.94 & $\mathrm{a}$ & 10.14 & $\mathrm{a}$ & 11.50 & $\mathrm{a}$ \\
\hline & GG 157 & 4.21 & $\mathrm{a}$ & 7.90 & $\mathrm{a}$ & 10.11 & $\mathrm{a}$ & 10.93 & $\mathrm{a}$ \\
\hline 1666 plants ha ${ }^{-1}$ & GG 100 & 3.82 & $\mathrm{a}$ & 7.68 & $\mathrm{a}$ & 10.18 & $\mathrm{a}$ & 11.06 & $\mathrm{a}$ \\
\hline
\end{tabular}

Averages followed by the same lowercase letter in the column for each spacing do not differ from each other by the Tukey test at the $5 \%$ probability level.

Table 5. Mean diameter at breast height (DBH), in centimeters, for clones GG 680, GG 157 and GG 100, in the six planting spacings, at 12,18, 24 and 32 months after planting.

\begin{tabular}{|c|c|c|c|c|c|c|c|c|c|}
\hline \multirow[t]{3}{*}{ Clone } & \multirow{3}{*}{$\begin{array}{l}\text { Spacing }(\mathrm{m}) \\
2.5 \times 0.5\end{array}$} & \multicolumn{8}{|c|}{ Diameter at breast height $(\mathrm{DBH})(\mathrm{cm})$} \\
\hline & & \multicolumn{2}{|c|}{12 months } & \multicolumn{2}{|c|}{18 months } & \multicolumn{2}{|c|}{24 months } & \multicolumn{2}{|c|}{32 months } \\
\hline & & 4.15 & $\mathrm{a}$ & 5.89 & $\mathrm{a}$ & 6.74 & $\mathrm{~b}$ & 7.65 & $\mathrm{~b}$ \\
\hline & $2.5 \times 1.0$ & 4.48 & a & 6.01 & a & 8.08 & $\mathrm{ab}$ & 8.97 & $\mathrm{~b}$ \\
\hline \multirow[t]{6}{*}{ GG 680} & $2.5 \times 2.0$ & 4.50 & a & 6.74 & a & 8.18 & $\mathrm{ab}$ & 9.10 & $\mathrm{~b}$ \\
\hline & $3.0 \times 0.5$ & 4.02 & a & 5.88 & a & 6.86 & $\mathrm{~b}$ & 7.69 & $\mathrm{~b}$ \\
\hline & $3.0 \times 1.0$ & 4.57 & a & 7.27 & a & 8.79 & $\mathrm{ab}$ & 9.54 & $\mathrm{ab}$ \\
\hline & $3.0 \times 2.0$ & 4.35 & a & 7.94 & $\mathrm{a}$ & 10.79 & $\mathrm{ab}$ & 9.54 & $a b$ \\
\hline & $2.5 \times 0.5$ & 3.26 & $\mathrm{a}$ & 5.32 & $\mathrm{c}$ & 6.33 & $\mathrm{c}$ & 7.49 & $\mathrm{c}$ \\
\hline & $2.5 \times 1.0$ & 4.08 & $\mathrm{a}$ & 7.75 & $a b$ & 8.18 & $a b c$ & 8.88 & $\mathrm{bc}$ \\
\hline \multirow[t]{6}{*}{ GG 157} & $2.5 \times 2.0$ & 5.16 & $\mathrm{a}$ & 8.42 & $\mathrm{a}$ & 10.41 & a & 11.16 & a \\
\hline & $3.0 \times 0.5$ & 4.06 & $\mathrm{a}$ & 6.08 & $\mathrm{bc}$ & 7.20 & $\mathrm{c}$ & 8.28 & $\mathrm{c}$ \\
\hline & $3.0 \times 1.0$ & 4.36 & $\mathrm{a}$ & 6.63 & $a b c$ & 8.01 & $\mathrm{bc}$ & 8.95 & $a b c$ \\
\hline & $3.0 \times 2.0$ & 4.21 & $\mathrm{a}$ & 7.90 & $a b$ & 10.11 & $\mathrm{ab}$ & 10.93 & $a b$ \\
\hline & $2.5 \times 0.5$ & 3.53 & $\mathrm{a}$ & 5.55 & $a b$ & 6.62 & $\mathrm{c}$ & 7.96 & $\mathrm{bc}$ \\
\hline & $2.5 \times 1.0$ & 3.60 & $\mathrm{a}$ & 6.08 & $a b$ & 7.83 & $\mathrm{bc}$ & 8.84 & $a b c$ \\
\hline \multirow[t]{4}{*}{ GG 100} & $2.5 \times 2.0$ & 3.60 & $\mathrm{a}$ & 6.87 & $a b$ & 9.15 & $a b$ & 10.08 & $a b$ \\
\hline & $3.0 \times 0.5$ & 3.13 & $\mathrm{a}$ & 5.10 & $\mathrm{~b}$ & 6.25 & $\mathrm{c}$ & 7.59 & $\mathrm{c}$ \\
\hline & $3.0 \times 1.0$ & 4.01 & $\mathrm{a}$ & 6.42 & $a b$ & 8.06 & $a b c$ & 8.92 & $a b c$ \\
\hline & $3.0 \times 2.0$ & 3.82 & $\mathrm{a}$ & 7.68 & $\mathrm{a}$ & 10.18 & $\mathrm{a}$ & 11.06 & $\mathrm{a}$ \\
\hline
\end{tabular}

Averages followed by the same lowercase letter in the column for each spacing do not differ from each other by the Tukey test at the $5 \%$ probability level.

For the evaluation time, regression analysis was performed, generating the equations (Table 6) for each diameter growth curve at each spacing within each clone.

Analyzing the curves of diameter growth for each clone in the studied spacings, it was observed that, in general, at 12 months there was still no differentiated behavior as a function of spacing, mainly for the GG 680 and GG 100 clones. Around 18 months, it was observed that the clones began to show differentiated growth behavior as a function of the studied spacings (Figure 2). 
Table 6. Equations of diameter growth curves obtained from regression, for the time unfolding within each clone for each spacing.

\begin{tabular}{|c|c|c|c|c|c|}
\hline \multicolumn{2}{|c|}{ Treatments } & \multicolumn{3}{|c|}{ Coefficients } & \multirow{2}{*}{$\mathrm{R}^{2}(\%)$} \\
\hline Clone & Spacing & $\beta_{0}$ & $\beta_{1}$ & $\beta_{2}$ & \\
\hline \multirow{6}{*}{ GG 680} & $2.5 \mathrm{~m} \times 0.5 \mathrm{~m}$ & -0.269147 & 0.447759 & -0.006288 & 99.46 \\
\hline & $2.5 \mathrm{~m} \times 1.0 \mathrm{~m}$ & -0.963671 & 0.523255 & -0.006584 & 98.47 \\
\hline & $2.5 \mathrm{~m} \times 2.0 \mathrm{~m}$ & -2.017161 & 0.662185 & -0.009841 & 99.99 \\
\hline & $3.0 \mathrm{~m} \times 0.5 \mathrm{~m}$ & -1.029558 & 0.514870 & -0.007593 & 99.72 \\
\hline & $3.0 \mathrm{~m} \times 1.0 \mathrm{~m}$ & -3.555101 & 0.840941 & -0.013510 & 99.94 \\
\hline & $3.0 \mathrm{~m} \times 2.0 \mathrm{~m}$ & -6.116186 & 1.068965 & -0.016212 & 99.97 \\
\hline \multirow{6}{*}{ GG 157} & $2.5 \mathrm{~m} \times 0.5 \mathrm{~m}$ & -1.900738 & 0.520127 & -0.007123 & 99.42 \\
\hline & $2.5 \mathrm{~m} \times 1.0 \mathrm{~m}$ & -5.364907 & 1.022472 & -0.018175 & 94.96 \\
\hline & $2.5 \mathrm{~m} \times 2.0 \mathrm{~m}$ & -5.081119 & 1.060964 & -0.017296 & 100.00 \\
\hline & $3.0 \mathrm{~m} \times 0.5 \mathrm{~m}$ & -1.220789 & 0.531809 & -0.007365 & 99.75 \\
\hline & $3.0 \mathrm{~m} \mathrm{x} 1.0 \mathrm{~m}$ & -2.124034 & 0.659980 & -0.009820 & 99.96 \\
\hline & $3.0 \mathrm{~m} \mathrm{x} 2.0 \mathrm{~m}$ & -7.346373 & 1.199331 & -0.019631 & 100.00 \\
\hline \multirow{6}{*}{ GG 100} & $2.5 \mathrm{~m} \times 0.5 \mathrm{~m}$ & -1.301375 & 0.478910 & -0.005957 & 99.50 \\
\hline & $2.5 \mathrm{~m} \times 1.0 \mathrm{~m}$ & -3.835260 & 0.752691 & -0.011140 & 100.00 \\
\hline & $2.5 \mathrm{~m} \times 2.0 \mathrm{~m}$ & -6.746697 & 1.060722 & -0.016703 & 99.96 \\
\hline & $3.0 \mathrm{~m} \times 0.5 \mathrm{~m}$ & -1.669991 & 0.472836 & -0.005761 & 99.70 \\
\hline & $3.0 \mathrm{~m} \mathrm{x} 1.0 \mathrm{~m}$ & -3.298558 & 0.745255 & -0.011358 & 100.00 \\
\hline & $3.0 \mathrm{~m} \times 2.0 \mathrm{~m}$ & -8.484805 & 1.272307 & -0.020666 & 99.99 \\
\hline
\end{tabular}
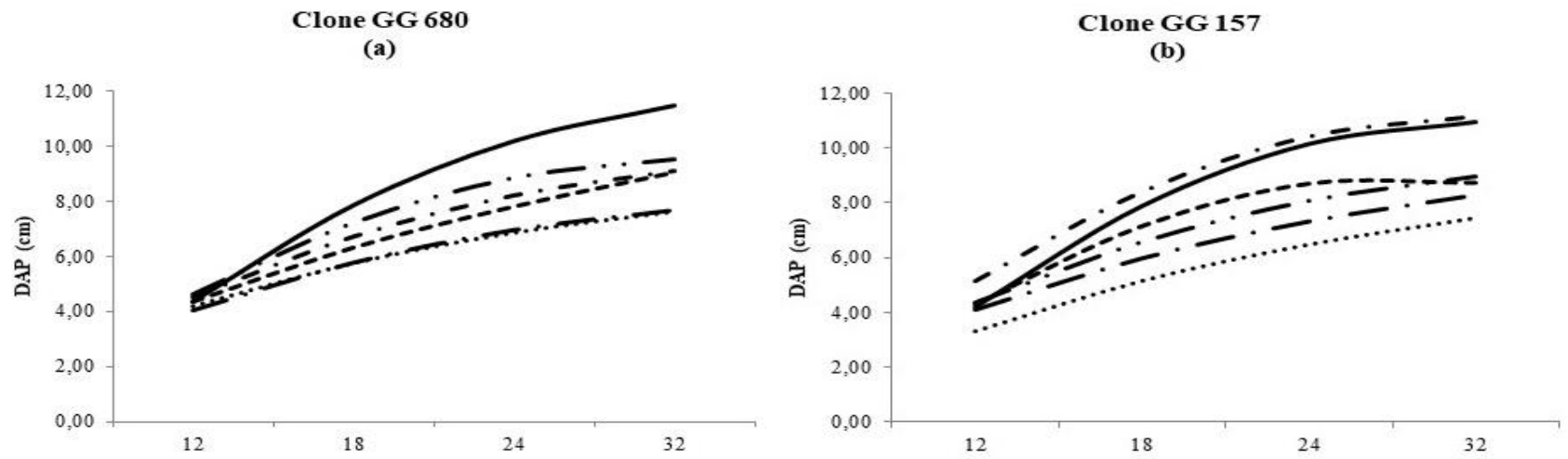

\section{Clone GG 100}

(c)

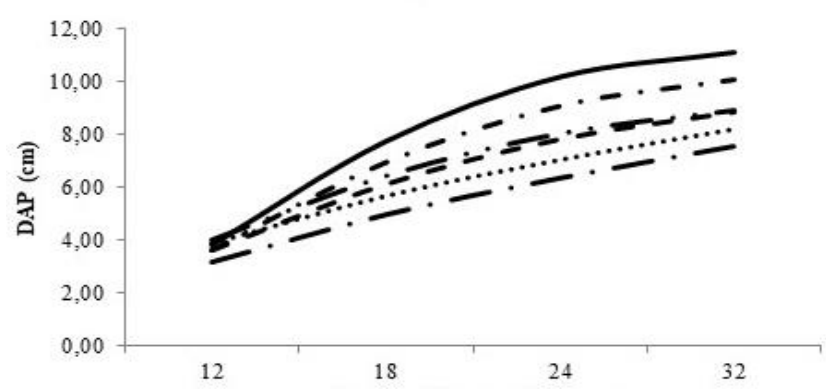

Tempo após o plantio (meses)

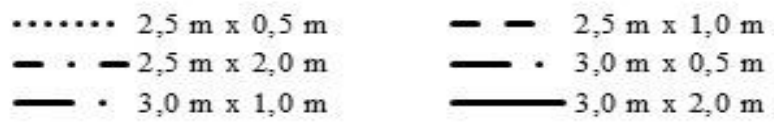

Figure 2. Diameter growth (DBH) curves for clones GG 680 (a), GG 157 (b) and GG 100 (c), for the different spacings studied. 
For clone GG 680, the best performance was at $3.0 \mathrm{~m} \times 2.0 \mathrm{~m}$ spacing. At 32 months, the curve keeps accented, showing a tendency to continue growing in diameter (Figure 2). Even at this age for the $3.0 \mathrm{~m} \mathrm{x} 1.0$ $\mathrm{m}, 2.5 \mathrm{~m} \times 2.0 \mathrm{~m}$ and $2.5 \mathrm{~m} \times 1.0 \mathrm{~m}$ spacings, which have similar performance, there is a reduction in growth. The smallest spacings $(3.0 \mathrm{~m} \times 0.5 \mathrm{~m}$ and $2.5 \mathrm{~m}$ $\mathrm{x} 0.5 \mathrm{~m}$ ) presented the lowest growth rate.

For clone GG 157, the same behavior was detected in the largest spacings $(2.5 \mathrm{~m} \times 2.0 \mathrm{~m}$ and $3.0 \mathrm{~m} \times 2.0$ $\mathrm{m})$, with a steeper curve from approximately 18 months of age. The $2.5 \mathrm{~m} \times 1.0 \mathrm{~m}$ spacing, which had been showing a higher growth compared to $3.0 \mathrm{~m} \mathrm{x} 1.0 \mathrm{~m}$, after 24 months showed growth stagnation, equaling at 32 months the behavior observed at $3.0 \mathrm{~m} \mathrm{x} 1.0 \mathrm{~m}$ spacing. There was a break of plant tops around 24 months. After the break of plant top, plants allocate photoassimilates to regain their growth in height and, consequently, reduce the amount of these, which are used for growth in diameter.

Analyzing clone GG 100, it was observed that diameter growth followed the area available for plant growth, showing better performance as the available area for each plant increased. Thus, the best performance was observed at the $3.0 \mathrm{~m} \times 2.0 \mathrm{~m}$ spacing $\left(6.0 \mathrm{~m}^{2}\right.$ plant $\left.^{-1}\right)$, followed by the $2.5 \mathrm{~m} \mathrm{x} 2.0 \mathrm{~m}\left(5.0 \mathrm{~m}^{2}\right.$ plant $\left.{ }^{-1}\right), 3,0 \mathrm{~m} \mathrm{x} 1.0 \mathrm{~m}\left(3.0 \mathrm{~m}^{2}\right.$ plant $\left.^{-1}\right)$ and $2.5 \mathrm{~m} \mathrm{x} 1.0$ $\mathrm{m}\left(2.5 \mathrm{~m}^{2}\right.$ plant $\left.^{-1}\right)$ spacings. In the spacings with higher density, there was an inversion: the $2.5 \mathrm{~m} \mathrm{x} 0.5 \mathrm{~m}$ spacing $\left(1.25 \mathrm{~m}^{2}\right.$ plant $\left.^{-1}\right)$ had better growth than $3.0 \mathrm{~m} \mathrm{x}$ $0.5 \mathrm{~m}$ spacing $\left(1.5 \mathrm{~m}^{2}\right.$ plant $\left.^{-1}\right)$ until 32 months.

\section{Wood volumetric production}

Individual volumetric production and per hectare showed significant influence for clone and spacing factors, in isolation, as well as for the interaction between the two factors at $1 \%$ probability (Table 7 ).

Analyzing the volumetric production per tree as a function of spacing (Table 8), it was observed that the clones studied showed different performance for the same spacing and between different spacings. Clone GG100 was the one with the highest wood volume per tree $\left(0.0383 \mathrm{~m}^{3}\right)$ at $2.5 \times 0.5 \mathrm{~m}$ spacing, while GG 157 and GG 680 did not differ in this spacing. It also obtained the highest individual wood production at $2.5 \mathrm{x}$ $1.0 \mathrm{~m}$ spacing $\left(0.0499 \mathrm{~m}^{3}\right)$.

For the $2.5 \times 2.0 \mathrm{~m}$ and $3.0 \times 0.5 \mathrm{~m}$ spacings, clone GG 157 presented the highest wood volume per tree $\left(0.0731 \mathrm{~m}^{3}\right.$ and $0.0388 \mathrm{~m}^{3}$, respectively), and GG 100 , the smallest individual volume $\left(0.0590 \mathrm{~m}^{3}\right.$ and 0.0305 $\mathrm{m}^{3}$, respectively) (Table 8). Clone GG 680 was the one that obtained the highest wood production per tree at 3.0 $\mathrm{x} 1.0 \mathrm{~m}$ and $3.0 \times 2.0 \mathrm{~m}$ spacings $\left(0.0519 \mathrm{~m}^{3}\right.$ and 0.0770 $\mathrm{m}^{3}$, respectively), while the smallest wood volume was observed for GG $157\left(0.0413 \mathrm{~m}^{3}\right.$ and $0.0660 \mathrm{~m}^{3}$, respectively).

In general, for the three clones, the volumetric productions increased with the increasing spacing (Table 8). For clones GG 680 and GG 100, the largest wood volumes per plant were found at the $3.0 \times 2.0 \mathrm{~m}$ spacing $\left(0.0770 \mathrm{~m}^{3}\right.$ and $0.0705 \mathrm{~m}^{3}$, respectively), and in GG 157 this was observed at the $2.5 \times 2.0 \mathrm{~m}$ spacing $\left(0.0731 \mathrm{~m}^{3}\right)$.

Table 7. Variance analysis of interactions between clone and spacing in relation to individual wood volume and wood volume per hectare.

\begin{tabular}{|c|c|c|c|c|c|c|}
\hline \multirow{2}{*}{ Source of variation } & \multirow{2}{*}{\multicolumn{6}{|c|}{$\begin{array}{cr}\text { Mean square } & \text { Fc } \\
\end{array}$}} \\
\hline & \multicolumn{5}{|c|}{ Individual wood volume $\left(\mathrm{m}^{3}\right.$ plant $\left.^{-1}\right)$} & \\
\hline Block & 2 & 0.001117 & 0.002054 & 0.037 & 0.9639 & ns \\
\hline Clone & 2 & 0.000044 & 0.000022 & 13.365 & 0.0001 & $* *$ \\
\hline Spacing & 5 & 0.011040 & 0.002208 & 1328.424 & 0.0000 & $* *$ \\
\hline Clone*Spacing & 10 & 0.000987 & 0.000099 & 52.357 & 0.0000 & $* *$ \\
\hline Error & 34 & 0.000057 & 0.000002 & & & \\
\hline Total corrected & 53 & 0.012127 & & & & \\
\hline \multirow[t]{2}{*}{$\mathrm{CV}(\%)$} & 2.62 & Over & & 0.0492 & & \\
\hline & \multicolumn{6}{|c|}{ Wood volume per hectare $\left(\mathrm{m}^{3} \mathrm{ha}^{-1}\right)$} \\
\hline Block & 2 & 31.810 & 15.9051 & 0.556 & 0.5789 & ns \\
\hline Clone & 2 & 406.300 & 203.1500 & 7.095 & 0.0027 & $* *$ \\
\hline Spacing & 5 & 156124.366 & 31224.8732 & 1090.568 & 0.0000 & $* *$ \\
\hline Clone*Spacing & 10 & 16930.724 & 1693.0724 & 59.133 & 0.0000 & $* *$ \\
\hline Error & 34 & 973.479 & 28.6317 & & & \\
\hline Total corrected & 53 & 174466.679 & & & & \\
\hline $\mathrm{CV}(\%)$ & 2.97 & Over & & 179.8778 & & \\
\hline
\end{tabular}


Table 8. Individual wood volume and wood volume per hectare for clones GG 680, GG1 57 and GG 100, at different planting spacing (Spc.), at 32 months of age.

\begin{tabular}{lcccccc}
\hline Clone/Spc. $(\mathrm{m})$ & \multicolumn{5}{c}{ Individual wood volume $\left(\mathrm{m}^{3} \mathrm{plant}^{-1}\right)$} \\
\cline { 2 - 7 } & $2.5 \times 0.5 \mathrm{~m}$ & $2.5 \times 1.0 \mathrm{~m}$ & $2.5 \times 2.0 \mathrm{~m}$ & $3.0 \times 0.5 \mathrm{~m}$ & $3.0 \times 1.0 \mathrm{~m}$ & $3.0 \times 2.0 \mathrm{~m}$ \\
\hline GG 680 & $0.0325 \mathrm{~b} \mathrm{E}$ & $0.0444 \mathrm{~b} \mathrm{D}$ & $0.0631 \mathrm{~b}$ & $0.0335 \mathrm{~b} \mathrm{E}$ & $0.0519 \mathrm{a} \mathrm{C}$ & $0.0770 \mathrm{a}$ \\
GG 157 & $0.0303 \mathrm{~b} \mathrm{D}$ & $0.0403 \mathrm{c}$ & $0.0731 \mathrm{a}$ & $0.0388 \mathrm{a} \mathrm{C}$ & $0.0413 \mathrm{c}$ & $0.0660 \mathrm{c} \mathrm{B}$ \\
GG 100 & $0.0383 \mathrm{a} \mathrm{E}$ & $0.0499 \mathrm{a} \mathrm{C}$ & $0.0590 \mathrm{c} \mathrm{B}$ & $0.0305 \mathrm{c} \mathrm{F}$ & $0.0445 \mathrm{~b} \mathrm{D}$ & $0.0705 \mathrm{~b} \mathrm{~A}$ \\
\hline \multicolumn{7}{c}{ Wood volume per hectare $\left(\mathrm{m}^{3} \mathrm{ha}^{-1}\right)$} \\
GG 680 & $259.84 \mathrm{~b} \mathrm{~A}$ & $177.65 \mathrm{~b} \mathrm{C}$ & $126.27 \mathrm{~b} \mathrm{E}$ & $223.62 \mathrm{~b}$ & $173.10 \mathrm{a} \mathrm{C}$ & $128.32 \mathrm{a} \mathrm{E}$ \\
GG 157 & $242.28 \mathrm{c} \mathrm{B}$ & $161.25 \mathrm{c}$ & $146.26 \mathrm{a} \mathrm{D}$ & $258.80 \mathrm{a}$ & $137.58 \mathrm{~b} \mathrm{D}$ & $109.95 \mathrm{~b} \mathrm{E}$ \\
\hline
\end{tabular}

For each variable analyzed, means followed by the same uppercase letter in the row and lowercase in the column do not differ from each other by the Tukey test at the 5\% probability level.

In larger spacings, there is less competition between plants for growth factors such as water, light, space, and nutrients, thus presenting higher growth and, consequently, larger wood volume (Martins et al., 2009). In planting with higher density, the greater competition for light and space that is established between the trees accelerates the stagnation of volumetric growth.

About the wood production per unit area (Table 8), it was observed an inverse behavior to that obtained for the individual wood volume. For clones GG 680 and GG 100, the highest productions were observed at $2.5 \mathrm{x}$ $0.5 \mathrm{~m}$ spacing $\left(259.84 \mathrm{~m}^{3} \mathrm{ha}^{-1}\right.$ and $306.36 \mathrm{~m}^{3} \mathrm{ha}^{-1}$, respectively) and the smallest at $3.0 \times 2.0 \mathrm{~m}\left(128.32 \mathrm{~m}^{3}\right.$ $\mathrm{ha}^{-1}$ and $117.48 \mathrm{~m}^{3} \mathrm{ha}^{-1}$, respectively) and $2.5 \mathrm{x} 2.0 \mathrm{~m}$ (126.27 $\mathrm{m}^{3} \mathrm{ha}^{-1}$ and $117.91 \mathrm{~m}^{3} \mathrm{ha}^{-1}$, respectively) spacings. In clone GG 157 , the highest wood production per hectare was found at $3.0 \times 0.5 \mathrm{~m}\left(258.80 \mathrm{~m}^{3} \mathrm{ha}^{-1}\right)$ and, the smallest at $3.0 \times 2.0 \mathrm{~m}\left(109.95 \mathrm{~m}^{3} \mathrm{ha}^{-1}\right)$.

The use of spacing with higher density produces trees of reduced diameter, resulting in trees with low individual wood volume (Silveira et al., 2014). However, in these spacings, there are more plants per unit area, resulting in lower rotations, larger basal area, and volume per hectare (Sereghetti et al., 2015). In forests managed for energy purposes, the objective is to produce the largest volume of total biomass per hectare, since even the branches can be used to transform wood into chips. Thus, higher wood volumetric production can result in higher energy yield if the technological characteristics of the wood are appropriate for this purpose.

\section{Conclusions}

Tree growth and wood production were influenced by the clones and spacings studied.

The average tree diameter increased with the planting spacing for the three clones studied.
In the largest spacings, the highest average heights were observed, with reduction of growth from 24 months, except for GG 680 clone, at the $2.5 \times 2.0 \mathrm{~m}$ and $2.5 \times 1.0 \mathrm{~m}$ spacings, and in the GG 100 clone, at $2.5 \times$ $1.0 \mathrm{~m}$ spacing.

The volume of wood per tree increased with the spacing for the three clones, while the volume per area was higher in the denser spacing.

The GG 100 clone planted at the $2.5 \mathrm{~m} \times 0.5 \mathrm{~m}$ spacing presented the highest volume of wood per unit area, producing $306.36 \mathrm{~m}^{3} \mathrm{ha}^{-1}$.

\section{Bibliographic References}

Bernardo, A.L., Reis, M.G.F., Reis, G.G., Harrison, R.B., Firme, D.J., 1998. Effect of spacing on growth and biomass distribution in Eucalyptus camaldulensis, E. pellita and E. urophylla plantations in southeastern Brazil. Forest Ecology and Management, 104, 1-13.

Brito, J.O., 2007. O uso energético da madeira. Estudos Avançados, 21, 185-193.

Cunha, F.F., Magalhães, F.F., Castro, M.A., 2013. Métodos para estimativa da evapotranspiração de referência para Chapadão do Sul - MS. Engenharia na Agricultura, 21, 159172.

Empresa Brasileira de Pesquisa Agropecuária - Embrapa, 2013. Sistema brasileiro de classificação de solos, terceira ed. Brasília.

Ferreira, D.H.A.A., Leles, P.S.S., Machado, E.C., Abreu, A.H.M., Abilio, F.M., 2014. Crescimento de clone de Eucalyptus urophylla $\mathrm{x}$ E. grandis em diferentes espaçamentos. Revista Floresta, 44, 431-440.

Harrington, T.B., Harrington, C.A., Debell, D.S., 2009. Effects of planting spacing and site quality on 25-year growth and mortality relationships of Douglas-fir (Pseudotsuga menziesii var. menziesii). Forest Ecology and Management, 258, 18-25.

Inoue, M.T., Figueiredo Filho, A., Lima, R., 2011. Influência do espaço vital de crescimento na altura e diâmetro de Pinus taeda L. Scientia Forestalis, 39, 377-385. 
Leite, F.P., Barros, N.F., Novais, R.F., Sans, L.M.A., Fabres, A.S., 1997. Crescimento de Eucalyptus grandis em diferentes densidades populacionais. Revista Arvore, 21, 313-321.

Leles, P.S.S., Reis, G.G., Reis, M.G.F., Morais, E.J., 2001. Crescimento, produção e alocação de matéria seca de Eucalyptus camaldulensis e E. pellita sob diferentes espaçamentos na região de cerrado, MG. Scientia Forestalis, $59,77-87$

Lima, I.L., Garcia, J.N., 2011. Efeito do desbaste e da fertilização na porcentagem de casca e conicidade de toras de Eucalyptus grandis. Revista Floresta, 41, 305-312.

Lopes, E.D., Laia, M.L., Santos, A.S., Soares, G.M., Leite, R.W.P., Martins, N.S., 2017. Influência do espaçamento de plantio na produção energética de clones de Corymbia e Eucalyptus. Revista Floresta, 47, 95-104.

Martins, R.J., Seixas, F., Stape, J.L., 2009. Avaliação técnica e econômica de um harvester trabalhando em diferentes condições de espaçamento e arranjo de plantio em povoamento de eucalipto. Scientia Forestalis, 37, 253-263.

Moulin, J.C., Arantes, M.D.C., Vidaurre, G.B., Paes, J.B., Carneiro, A.C.O., 2015. Efeito do espaçamento, da idade e da irrigação nos Componentes químicos da madeira de eucalipto Revista Árvore, 39, 199-208.

Oliveira Neto, S.N., Reis, G.G., Reis, M.G.F., Leite, H.G., Neves, J.C.L., 2010. Crescimento e distribuição diamétrica de Eucalyptus camaldulensis em diferentes espaçamentos e níveis de adubação na região de cerrado de Minas Gerais. Revista Floresta, 40, 755-762.

Protásio, T.P., Neves, T.A., Reis, A.A., Trugilho, P.F., 2014. Efeito da idade e clone na qualidade da madeira de Eucalyptus spp visando à produção de bioenergia. Ciência Florestal, 24, 465-477.

Sereghetti, G.C., Lanças, K.P., Sartori, M.S., Rezende, M.A., Soler, R.R., 2015. Efeito do espaçamento no crescimento e na densidade básica da madeira de Eucalyptus urophylla x Eucalyptus grandis em florestas de ciclo curto. Energia na Agricultura, 30, 257-262.

Silveira, E.D., Reiner, D.A., Smaniotto, J.R., 2014. Efeito do espaçamento de plantio na produção de madeira e serapilheira de Eucalyptus dunni na região sudoeste do Paraná, segunda ed. Revista Técnico-Científica do Crea-PR.

Soares, C.P.B., Paula Neto, F., Souza, A.L., 2007. Dendrometria e Inventário Florestal. Editora UFV, Viçosa.

Souza, M.O.A., Silva, J.C., Della Lucia, R.M., Evangelista, W.V., 2009. Avaliação da madeira de Eucalyptus camaldulensis Dehnh e Eucalyptus urophylla S.T. Blake em ensaios de usinagem, visando à produção moveleira. Revista Árvore, 33, 751-758.

Stape, J.L., Binkley, D., Ryan, M.G., Fonseca, R.A., Loos, R.A., 2010. The Brazil eucalyptus potential productivity project: influence of water, nutrients and stand uniformity on Wood production. Forest Ecology and Management, 259, 1684-1694. 